TecnoLógicas

ISSN-p 0123-7799

ISSN-e 2256-5337

Vol. 21, No. 42, pp. 13-30

Mayo-agosto de 2018

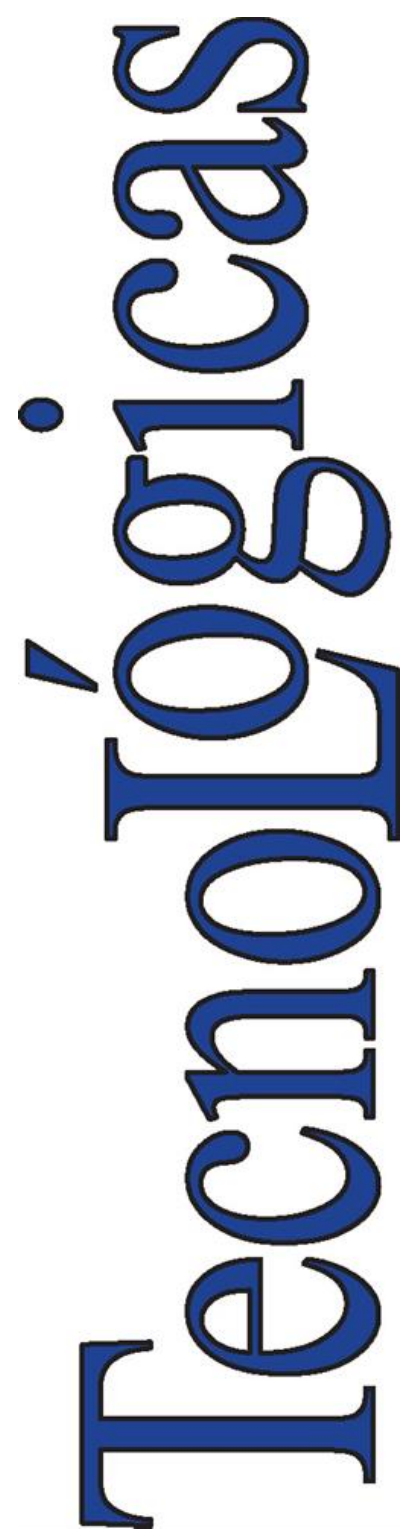

(C) Copyright 2015 por autores y Tecno Lógicas Este trabajo está licenciado bajo una Licencia Internacional Creative Commons Atribución (CC BY)

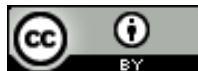

Artículo de Reflexión/ Reflection Article

\section{Integration of distributed energy resources in isolated microgrids: the Colombian paradigm}

\section{Integración de los recursos energéticos distribuidos en microrredes aisladas: paradigma colombiano}

\author{
Dahiana López-García ${ }^{1}$, Adriana Arango-Manrique ${ }^{2}$, y \\ Sandra X. Carvajal-Quintero ${ }^{3}$
}

Recibido: 09 de octubre de 2017

Aceptado: 03 de abril de 2018

Cómo citar / How to cite

D. López-García, A. Arango-Manrique, y S. X.-Carvajal-Quintero, Integration of distributed energy resources in isolated microgrids: the Colombian paradigm. TecnoLógicas, vol. 21, no. 42, pp. 13-29, 2018.

1 Electrical Engineer, Faculty of Engineering and Architecture, Department of Electrical, Electronic and Computer Engineering, Research Group Environmental Energy and Education Policy - E3P, Universidad Nacional de Colombia, Manizales-Colombia, dahlopezgar@unal.edu.co

$2 \mathrm{PhD}$ in Engineering, M.Sc. in Engineering, Electrical Engineer, Faculty of Engineering and Architecture, Department of Electrical, Electronic and Computer Engineering, Research Group Environmental Energy and Education Policy - E3P, Universidad Nacional de Colombia, ManizalesColombia, aarangoma@unal.edu.co

$3 \mathrm{PhD}$ in Engineering, M.Sc. in Engineering, Electrical Engineer, Faculty of Engineering and Architecture, Department of Electrical, Electronic and Computer Engineering, Research Group Environmental Energy and Education Policy - E3P, Universidad Nacional de Colombia, ManizalesColombia, sxcarvajalq@unal.edu.co 


\section{Abstract}

The electrification of rural or isolated areas coupled with increasing environmental concerns have promoted the emergence of Distributed Energy Resources (DER) and the operation by isolated microgrids. However, the integration of such resources involves technical issues related to the reliability and continuity of the electricity supply. Indeed, the uncertainty of renewable generation sources and the reduced inertia of isolated microgrids are challenges for the operation of these distribution systems. One way to address them is by providing ancillary services through all the resources involved in the system's operation (generation assets, demand share, and storage systems). Accordingly, this paper first presents a literature review of the challenges and potential benefits of integrating DERs into the operation of a distribution system. It also includes some common strategies to mitigate the vulnerability of the introduction of these technologies in microgrids. Afterwards, the current state of each type of resource in Colombia is assessed. Finally, some basic strategies that enhance the benefits of DER integration are outlined along with the overcoming of challenges of microgrid operation in said country. To that end, we consider isolated Colombian regions to be natural laboratories where the effects of DER integration and the requirements for the operation by local production units can be analyzed.

\section{Keywords}

Ancillary Services; Distributed Energy Resource; Isolated Grids; Microgrids; Technical Sustainability.

\section{Resumen}

La electrificación de áreas rurales o aisladas, junto con las crecientes preocupaciones ambientales, han promovido la aparición de Recursos Energéticos Distribuidos (DER), y la operación por microrredes aisladas. Sin embargo, la integración de dichos recursos trae consigo problemas técnicos relacionados con la confiabilidad y la continuidad del suministro de electricidad. De hecho, la variabilidad e incertidumbre del recurso primario de las fuentes de generación renovables y la poca inercia de las microrredes aisladas son desafíos que se enfrentan en la operación de estos sistemas de distribución. Una forma de responder a estos desafíos es brindando servicios complementarios a través de todos los recursos inmersos en el funcionamiento del sistema (activos de generación, participación de la demanda y sistemas de almacenamiento). Este artículo muestra una revisión de los desafíos y beneficios potenciales de la Integración de DER, en la operación del sistema de distribución reportados en la literatura, junto con algunas estrategias comunes para mitigar la vulnerabilidad de la introducción de estas tecnologías en microrredes. Asimismo, realiza una evaluación del estado actual de cada recurso en Colombia; finalmente, se describen algunas estrategias para aumentar del impacto de los beneficios de la Integración de DER y la superación de algunos desafíos planteados en la operación por microredes en Colombia. Para ello, se considera a las regiones aisladas de Colombia como un laboratorio natural, donde sería posible analizar los efectos de la Integración de DER, así como los requisitos para la operación por parte de las unidades de producción locales.

\section{Palabras clave}

Servicios complementarios; Recursos Energéticos Distribuidos; Redes Aisladas; Microrredes; Sostenibilidad técnica. 


\section{INTRODUCTION}

Electrical distribution networks that integrate generation near consumption centers, Energy Storage Systems (ESSs), and the active participation of the demand present challenges related to the operation, integration, and control of these resources, which are called DERs [1], [2]. This integration creates opportunities to define technical, regulatory, and economic strategies in order to guarantee a safe and reliable operation of isolated or interconnected microgrids [2]-[4], which enables the flexibility of the distribution network and allows the distribution system to provide ancillary services to the transmission system. In addition, the benefits that each agent offers can be leveraged to ensure that the operation by microgrids is sustainable over time. However, it is important to highlight that the inclusion of DERs in a distribution network introduces changes in the operation and management of the associated resources, especially significant differences between the operation of active and traditional distribution systems [3], [5]-[9].

For the operation of an active distribution system by isolated microgrids, it is necessary to include distributed generation (DG) plants with advanced control, as well as install measurement and control devices on the feeder and demand in order to constantly monitor the system. This integration enables to provide ancillary services included in all DERs, like voltage and frequency control, which enables the demand to have an active participation in the operation by isolated microgrids [10].

A flexible and reliable operation that maintains acceptable levels of safety, reliability, and quality is one of the challenges that emerge with DER integration. These concepts are linked to the resilience and the ability of isolated microgrids to provide a continuous supply of electricity to connected users despite the occurrence of events in the system (ancillary services) [11].

This paper seeks to review potential benefits and challenges that are faced when DERs are integrated into distribution systems (especially in isolated microgrids), the state of these resources in the Colombian paradigm, and international experiences related to this topic. The purpose is to define the next steps for the integration of DERs in Colombia by identifying non-interconnected areas as potential natural laboratories to study the behavior and control of these resources.

The paper is organized as follows: Section 1 introduces the integration and inclusion of DERs in the distribution system. Section 2 provides an overview of the situation of DERs in Colombia. Section 3 describes some international experiences related to the integration of DERs. Finally, Section 4 outlines some strategies for the integration of DERs in Colombia by defining the next steps the country should take to incorporate them into microgrid operation. Finally, some recommendations and conclusions are provided.

\section{INTEGRATION OF DISTRIBUTED ENERGY RESOURCES}

The evolution towards smart grids poses challenges related to the inclusion of DERs into the distribution systems [12], [13]. These challenges include the integration of active demand participation, DG, and ESS. Incorporating DERs (such as small-scale generation plants, ESS or standby generators) and active demand participation provide the system's operation with significant value due to operational and market changes [14].

The increase in generation connected near consumption centers, especially variable generation from renewable resources, has modified the operation of a conventional distribution system [15]. After DG installation, it is necessary to analyze the 
effects of the inclusion of these resources in the microgrid and plan its main characteristics, location alternatives, and installation time of each generator according to its technology. Furthermore, active distribution networks, as opposed to traditional distribution systems (which operate with unidirectional flows from the power system to the loads), have multidirectional flows caused by the increase of DG, storage systems and demand as an active agent with participation in the market.

The integration of small-scale generation into the distribution system changes the conventional operation scheme, which brings economic and technical benefits. In economic terms, the connection of these technologies to the distribution system reduces distribution costs caused by network congestion and reduces power losses and investment risks [16], [17], [18]. In technical terms, DG integration enables the distribution system to create microgrids as local production units [19], and it makes the most of the potential of this operation mode regarding congestion management, power losses reduction, enhancement of electricity supply reliability and improvement of voltage profiles [17], [18].

Besides, Demand Side Management (DSM) is defined as the planning, implementation, and supervision of activities aimed at producing changes in the consumption pattern for improving energy efficiency and operating the Electrical Power System (EPS) [20]-[22], which allows microgrids to get closer to the smart grid philosophy [20], [23].

In this regard, DSM has evolved into energy efficiency and demand response to economic and technical signals [20]. Demand response is the reflection of the action taken by a customer as a result of financial incentives. Nevertheless, the real value of demand response is the aggregation of impacts across the entire distribution network, which provides flexibility to the system at a low cost [24], [25]. Fur- thermore, the inclusion of active demand in the system's operation can mitigate the variability and uncertainty of renewable energy sources, which have been increasingly connected to the distribution system in recent years [26].

The integration of these new resources to the network leads to the evolution from current to active distribution networks, which migrate to the microgrid mode [27]. This mode of operation enables to maximize the integration of small-scale generation assets, automated distribution networks, and controllable loads to create electrical power subsystems that are independent of the central interconnected system [28].

However, in the mode of operation by isolated local production units, frequency and voltage control are fundamental, because the large inertia formed by the interconnection with the EPS is no longer available. Thus, the controllability of DERs in the microgrid guarantees the continuity and security of the electricity supply to connected users.

Including ESSs is recommended in order to achieve a flexible and reliable operation of isolated microgrids with the capacity to operate by local production units and with the integration of variable generation sources. This resource is one of the most critical and essential elements in microgrid operation, since it could guarantee an uninterrupted electricity supply.

When ESSs work as isolated local production units, their main application is to maintain balance between generation and demand, compensating the DG during voltage drops and frequency variations, and as backup to variable energy resources [17], [29], [30]. Additionally, these systems could provide ancillary services such as frequency control and reactive control (via inverters and converters), which would allow to reduce the outage time in restoration processes by increasing the safety margin in the operation by microgrids [28]. 
In order to enjoy of these benefits, it is necessary to consider the location of the ESS and DG and have control and communication systems. This allows the grid to maintain constant supervision and guarantee the balance among generation, demand, and charge level of the ESS [27]. Additionally, optimizing the location of these DERs reduces congestion management and, subsequently, infrastructure and connection investments decrease [17], [18].

Therefore, DER integration in the operation by isolated microgrids has operational advantages for the dynamics of the grid, and it allows an efficient, reliable, and safe operation, as shown in Fig. 1.

One of the advantages of the microgrid operation is the increase in capacity of the lines due to demand changes [2], [3], [23], [24]. In addition, modifications in the consumption behavior of the demand may lead to an increase in the operational safety margin, thus reducing the likelihood of unplanned electricity blackouts and overcharges for restoration [24], [31]-[33]. These benefits are obtained because the operator has information and constant monitoring of the real-time values of the microgrid's variables; therefore, decisions can be made based on the permanent exchange of information and the dynamic operation can be based on the behavior of different agents in the system. These advantages are reinforced over time and lead to an efficient, reliable, and safe operation with flexibility levels [2], [24], [31], [34].

When DGs are connected to a microgrid, they have significant effects on power quality, stability, and voltage profiles; as a result, they can be considered a geographically localized voltage control [35], [36], [37]. The impact of these resources on power quality largely depends on the number of DERs installed in the system, i.e., massive and uncontrolled installation of these resources could have adverse effects on power quality [36]-[40].

However, one of the challenges of DER integration is a flexible and reliable operation, which allows the distribution network to isolate faults and maintain acceptable levels of safety, reliability, and quality in the electricity supply for connected users. These concepts are linked to the resilience of the active distribution networks and ancillary services, which give the system the capacity to provide a continuous service despite the occurrence of events [11].

Table 1 shows a summary of the benefits and the related challenges that would guarantee technical sustainability in the isolated or interconnected microgrid mode.

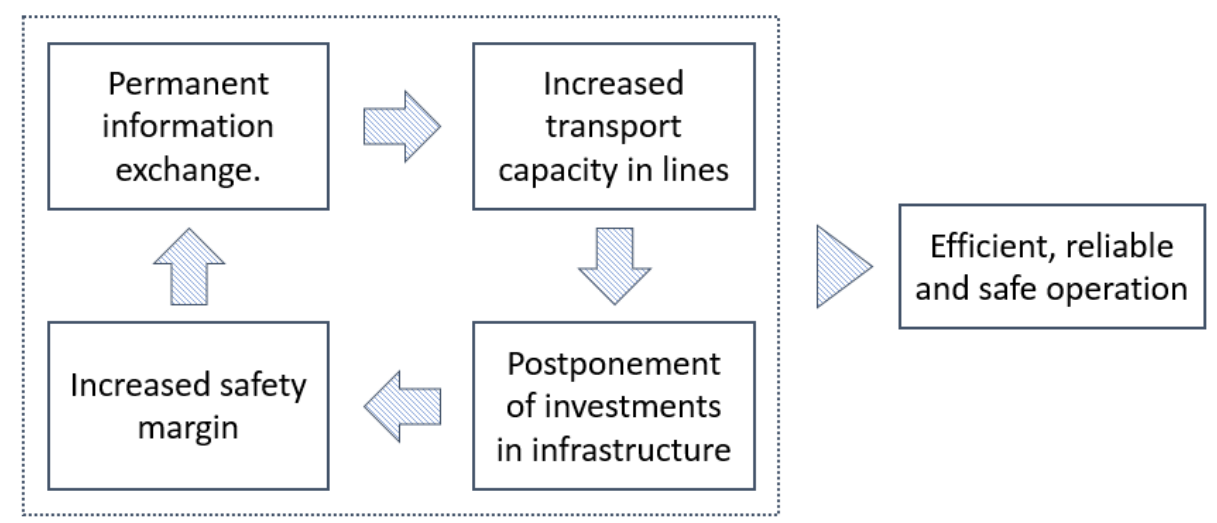

Fig. 1. Integration of DERs in microgrid operation. Source: Authors. 
Integration of distributed energy resources in isolated microgrids: the Colombian paradigm

Table 1. Benefits and challenges of DER integration. Source: Authors.

\begin{tabular}{|c|c|}
\hline Benefits & Challenges \\
\hline DG connected near consumption centers. & $\begin{array}{l}\text { Connecting power electronic devices may produce } \\
\text { distortions in the waveforms [39], [41]. }\end{array}$ \\
\hline $\begin{array}{l}\text { Reduction of electrical losses in the EPS [17], [28], } \\
\text { [37]. }\end{array}$ & Optimal location of DGs [42]. \\
\hline $\begin{array}{l}\text { Delay of the need for expansion in distribution } \\
\text { networks [15]. }\end{array}$ & $\begin{array}{l}\text { Optimal location of DGs and ESSs [42]. } \\
\text { Active participation of the demand [28]. }\end{array}$ \\
\hline $\begin{array}{l}\text { Reduction of the generation trapped in distribution } \\
\text { networks due to disconnection from the transmission } \\
\text { network [17], [28], [37]. }\end{array}$ & Flexible and reliable operation [27]. \\
\hline $\begin{array}{l}\text { Reduction of not supplied energy due to accidental } \\
\text { disconnections [43]. }\end{array}$ & $\begin{array}{l}\text { Implementation of island operation capacity as an } \\
\text { ancillary service in the voltage levels of the distribu- } \\
\text { tion system. }\end{array}$ \\
\hline
\end{tabular}

\section{CURRENT STATUS OF DERS IN COLOMBIA}

Electric power systems in Colombia fall into two main categories: the central interconnected system and isolated power supply zones (isolated generation units). The former, which mainly works with centralized generation, has a liberalized market since 1995 and it is known as the National Interconnected System (NIS); although it supplies $80 \%$ of the national demand, it only covers $48 \%$ of the national territory. The energy supply of the remaining territory $(52 \%)$ is provided by isolated generation units [44], which are characterized by operating with DG resources and having a predominantly residential demand [45].

Isolated areas in Colombia are grouped under the name of Non-Interconnected Zones (NIZ) and they are characterized by supplying electricity to populations located far from the centers that concentrate the largest population and that present difficult road access [46]. These zones consist of 1,448 communities in tropical forests, deserts, and snowy mountains, specifically, most of the protected national environmental areas and the 26 national parks are located in the departments that comprise the NIZ [46]. Fig. 2 shows the NIZ in Colombia and the main energy sources used in those isolated microgrids.
Most of the 1,448 municipalities that are part of the NIZ use diesel, and only ten of them operate projects that integrate renewable energy with diesel production units to supply electricity to small communities. Table 2 shows the installed capacity of these projects and their technology.

In addition, Table 3 shows some photovoltaic projects that are about to be developed in the NIZ, which reveals the need for regulating the integration of DERs in these areas. These projects represent potential laboratories for the integration of DERs in isolated microgrids and microgrid operation, since they can provide technical and economic information on the operation of these technologies in such areas, which would be an essential tool for the definition of adequate regulations.

The provision of the electric power service in the NIZ is one of the main unsatisfied needs related to the public utilities of these populations. The reduced diversity of energy generation resources, specifically the use of fossil fuels such as diesel oil or fuel increases the cost of energy generation. In this regard, the National Government through Article 62 of Law 812 of 2003 and the Ministry of Mines and Energy allowed the subsidies earmarked for the users located in the NIZ to be used to cover the costs of the fuel required by the generation plants in these areas [52]. 


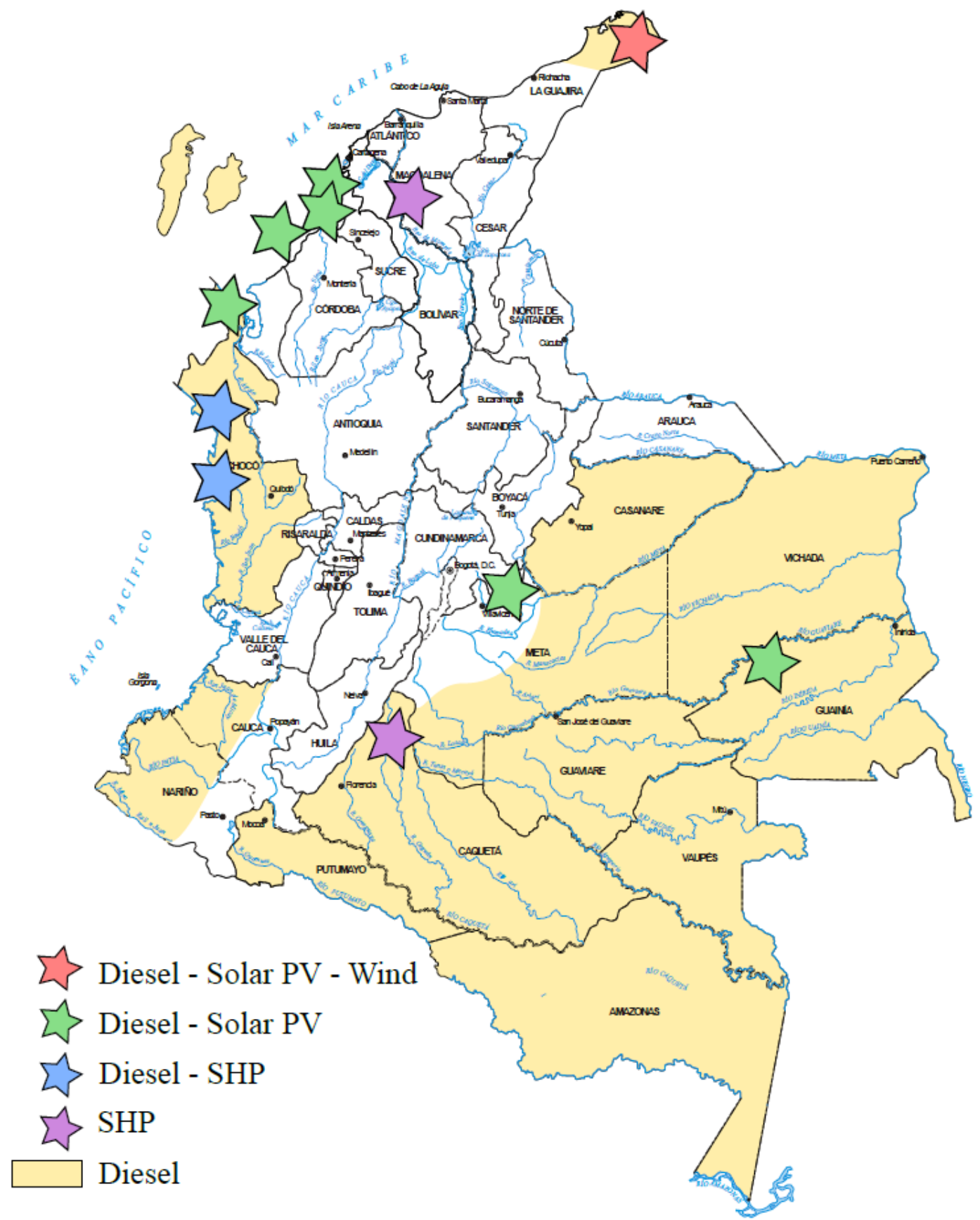

Fig. 2. Energy sources used for energy generation in the NIZ. Source: Compiled by the authors based on [47]-[49].

Consequently, the provision of the electricity services in the NIZ is different from the operation mode of the NIS because the supply by agents is not diversified and the operation rules are exclusive to the operation of the distribution system of these zones. This implies that, in the NIZ, ser- vice providers can carry out the generation, distribution, and commercialization activities in an integrated way [53]. Table 4 shows the main operational characteristics of the EPS in Colombia and the variety of DERs used in the NIS and the NIZ [54]. 
Integration of distributed energy resources in isolated microgrids: the Colombian paradigm

Table 2. Renewable energy integration projects in Colombia. Source: Compiled by the authors based on [47]-[50].

\begin{tabular}{|c|c|c|c|c|c|c|}
\hline \multirow{2}{*}{ Project } & \multirow{2}{*}{ Department } & \multicolumn{5}{|c|}{ Capacity (kVA) } \\
\hline & & Diesel & Solar PV & Wind & SHP & Storage \\
\hline Isla Fuerte & Bolívar & 320 & 175 & 0 & 175 & 0 \\
\hline Isla Múcura & Bolívar & 116 & 30 & 0 & 0 & 5 \\
\hline Santa Cruz del Islote & Bolívar & 116 & 68 & 0 & 0 & 9.6 \\
\hline Nazareth* & Guajira & 364 & 320 & 200 & 0 & 320 \\
\hline Titumate & Chocó & 124 & 105 & 0 & 0 & 0 \\
\hline El Yucal & Chocó & 32 & 0 & 0 & 18 & 0 \\
\hline Cupica & Chocó & 125 & 0 & 0 & 300 & 0 \\
\hline Palmor & Magdalena & 0 & 0 & 0 & 300 & 0 \\
\hline Guacamayas & Caquetá & 0 & 0 & 0 & 150 & 0 \\
\hline Barranco Minas & Guainía & 301 & 59 & 0 & 0 & 2,8 \\
\hline Paratebueno & Cundinamarca & 18 & 22 & 0 & 0 & $* *$ \\
\hline
\end{tabular}

Table 3. Solar PV projects for NIZ registered at the end of 2017. Source: Compiled by the authors based on [50].

\begin{tabular}{|c|c|c|}
\hline Project & Department & $\begin{array}{c}\text { Capacity } \\
\text { (MVA) } \\
\text { Solar PV }\end{array}$ \\
\hline Finca Machijure & Meta & 3 \\
\hline 2MW Leticia & Amazonas & 2 \\
\hline Finca La Fazenda & Meta & 1 \\
\hline Soluciones fotovoltaicas Chocó & Chocó & 1 \\
\hline $\begin{array}{l}\text { Sistemas solares fotovoltaicos para el sector rural en } \\
\text { Zonas No interconectadas del municipio de Hato }\end{array}$ & Casanare & 0.33 \\
\hline $\begin{array}{l}\text { Soluciones fotovoltaicas veredas Corazón, Quebrada } \\
\text { Bonita y Ticole }\end{array}$ & Chocó & 0.074 \\
\hline $\begin{array}{l}\text { Soluciones Fotovoltaicas veredas Caño Nuevo y } \\
\text { Tisló }\end{array}$ & Chocó & 0.066 \\
\hline
\end{tabular}

\section{NATIONAL INITIATIVES TO INCLUDE DERS IN DISTRIBUTION SYSTEMS}

Law 1715 of 2014 defined the concept of DG as "the production of electricity near consumption centers, connected to a local distribution system" whose capacity depends on that of the system it is connected to. This Law also establishes some conditions for the commercialization of electrici- ty from non-conventional energy sources [62].

On the other hand, resolution CREG 030 of 2018 is focused on distributed generation (less than $0.1 \mathrm{MW}$ ) and industries that harness energy (less than $1 \mathrm{MW}$ ) in the bulk power system. Such resolution defines technical and commercial requirements to connect this technology and 
Table 4. Characteristics of the EPS in Colombia. Source: Authors.

\begin{tabular}{|c|c|c|}
\hline & NIS & NIZ [45] \\
\hline DG & $\begin{array}{l}\text { 59.4\% Small Hydro-Power, } 19,8 \% \text { Cogeneration } \\
\text { (predominantly based on biomass), 18.1\% Small } \\
\text { Thermal Plants, } 2.6 \% \text { Wind [55]. } \\
\text { Energy is purchased from smaller plants without the } \\
\text { need for these plants to offer their energy and com- } \\
\text { pete in the market at economies of scale, which are } \\
\text { typical of large generators [56]. }\end{array}$ & $\begin{array}{l}96.3 \% \text { of the total generation capacity } \\
\text { is diesel [57]. }\end{array}$ \\
\hline Demand classification & $\begin{array}{l}34 \% \text { industrial, } 30 \% \text { commercial, } 60 \% \text { residential. } \\
\text { [58] }\end{array}$ & $\begin{array}{l}80 \% \text { residential, } \\
20 \% \text { commercial }\end{array}$ \\
\hline Daily hours of service & 24 hours [59] & $\begin{array}{l}0-10 \text { hours in } 15 \text { municipalities. } \\
10-20 \text { hours in } 12 \text { municipalities. } \\
24 \text { hours a day in } 25 \text { municipalities. }\end{array}$ \\
\hline $\begin{array}{l}\text { Bidirectional meas- } \\
\text { urement in distribu- } \\
\text { tion networks }\end{array}$ & $\begin{array}{l}\text { AMR in primary substations and power concentrators } \\
\text { in some suburban areas. }\end{array}$ & $\begin{array}{l}\text { AMR in DG plants and in the demand } \\
\text { of some large consumption centers. }\end{array}$ \\
\hline $\begin{array}{l}\text { Participation of DG in } \\
\text { ancillary services }\end{array}$ & $\begin{array}{l}\text { Proposals for the black start provision [60] } \\
\text { Proposal for the provision of voltage control [38]. }\end{array}$ & None \\
\hline $\begin{array}{l}\text { Demand participation } \\
\text { in ancillary services }\end{array}$ & $\begin{array}{l}\text { Demand participation to overcome cases of energy } \\
\text { deficit as a last resort to consider [61]. }\end{array}$ & None \\
\hline
\end{tabular}

reduce the impact on the normal operation. This new technology includes the implementation of advanced metering, but the law does not differentiate incentives for generation from renewable or conventional sources.

Regarding technical support services, there is a technical study that suggests the Electricity and Gas Regulation Commission (CREG) to compel small hydro-power plants larger than $5 \mathrm{MW}$ to install blackstart equipment to support the system in restoration processes [60]. Additionally, a market characterization was proposed [38] for the provision of voltage control by DG plants in distribution systems.

With regard to the active participation of demand in the operation of the electrical power systems, Law 1715 of 2014, Decree 2492 of 2014, and resolutions CREG 011 of 2015, CREG 025 and 042 of 2016 established a mechanism of demand response that encourages the participation of the demand in times of scarcity via payments for controlled disconnections [64]-[67]. However, in the case of the NIZ, the only incentive related to DSM projects has been the Program for the Rational and Efficient Use of Energy and Non-Conventional Sources (PROURE in Spanish) defined by Law 697 of 2001 [68]. This program promotes the rational use of energy by raising awareness among the population about the limitations and generation costs of electricity [69]. Nevertheless, in these areas, the demand has not been considered as a resource with the potential to influence the operation of distribution networks.

Article 18 of the 2014-2020 National Development Plan enables to establish differential schemes for the provision of electric power services in difficult access areas, such as prepaid meters and remote disconnection systems, among others.

Additionally, the Ministry of Mines and Energy of Colombia jointly with the Ministry of Information Technologies and Communications requested the Inter-American Development Bank for technical cooperation to identify the most appropriate roadmap to implement smart grids in Colombia. This roadmap can be consulted in [70] and it consists of four components: i) Technical and economic feasibility study of 
smart grid technologies for the Colombian electricity sector. ii) Study for making recommendations at a regulatory and policy level for the development of smart grids in the Colombian electricity sector. iii) Dissemination and promotion of smart grids in Colombia. iv) Methodology for the evaluation of pilot projects in smart grids in Colombia.

The scope of this roadmap is the NIS, and the results of the analysis of the functionalities of smart grids can be extended from the NIS to the NIZ once these solutions have been successfully applied in the former.

\section{INTERNATIONAL EXPERIENCES OF DER INTEGRATION}

The operation by isolated microgrids offers the possibility of coordinating distributed energy resources in a decentralized way. In the world, there are a number of isolated microgrids associated with smart grid research on topics such as the stable and dynamic behavior of the microgrid and the operational philosophies when working in isolated or interconnected microgrid modes, among others [71].

The UW Microgrid (University of Wisconsin) was installed to conduct research on the behavior and control of diesel plants connected to the microgrid. Such system does not have an ESS. One of the most important conclusions of that research is that when the system works in an isolated manner, its reactive flows are high. Hence, the use of converters is proposed to regulate the delivered reactive power and the flows through the network [30].

The Kythnos microgrid, located in Greece, is an isolated network that supplies electricity to 12 houses. The control system used in such microgrid is based on the monitoring frequency of the ESS management. Additionally, a load disconnection control occurs when the charge level of the batteries is too low [71].
Hartley Bay in British Columbia, Canada, is a remote coastal village that operates an isolated minigrid that supplies electricity to a native community of 170 members. It relies on a set of three diesel generators (two of $420 \mathrm{~kW}$ and one of 210 $\mathrm{kW})$ to provide electricity to 20 commercial buildings and 62 residential units. Given the low efficiency of the $210-\mathrm{kW}$ generator, a demand response program has been deployed to use the generator as little as possible, thus optimizing the diesel dispatch. The demand response system, composed of 20 variable thermostats and twelve load controllers, was installed in commercial buildings and has been able to reduce the peak demand by $15 \%$ [72].

The Brinsbergen microgrid, located in the Netherlands, has a peak power capacity of $315 \mathrm{~kW}$ from solar PV combined with a storage system that supports the electricity supply during the hours of insufficient solar radiation. These technologies, together with an intelligent energy management system, allow the network to work continuously, 24 hours a day [71].

The Nanji Island (Zhejiang, China) has an isolated microgrid, whose energy matrix is composed of $1 \mathrm{MW}$ of wind energy, 545 $\mathrm{kW}$ of solar PV, $30 \mathrm{~kW}$ of marine energy and 1.6 MW of diesel generation. In addition, it has an ESS of $300 \mathrm{~kW}$. This microgrid supplies electricity to 2,400 people on the island [71]. Also, in the eastern part of the Fushan Island, there is a microgrid called Dongfushan with a hybrid generation system (solar/wind/diesel) and an installed capacity of $300 \mathrm{~kW}$. It is complemented with batteries to optimize the use of renewable generation and reduce the contribution of its diesel counterpart [71].

In the west coast of Scotland, the Isle of Eigg has a high renewable content power mini-grid. The project has been successful at integrating multiple renewable energy sources into a community system and reducing diesel generator use. The system is composed of $110 \mathrm{~kW}$ of hydro power, $24 \mathrm{~kW}$ from wind turbines and $32 \mathrm{~kW}$ of solar PV. 
The introduction of renewable energy sources is supported by load side management with energy monitors installed in all facilities and droop control of the system, based on battery charge level and frequency [72].

In Latin America, the Huatacondo microgrid in Chile supplies energy to 30 families by combining solar PV, wind and diesel generation. In order to compensate for the fluctuations of the variable generation, $73 \%$ of the demand has an active participation in the system operation, which responds to the variations of network indicators. Additionally, a SCADA system was implemented to characterize the electricity requirements of the users connected to this isolated microgrid [73].

Table 5 shows a summary of the main characteristics, such as generation technologies and control systems, of some of the most important isolated microgrids.

The number of experiences with microgrids at an international level has increased in previous years because it is a sustainable solution for rural electrification that integrates renewable energies with diesel generation. Microgrids also involve the community in the construction, operation, and maintenance processes, which happens in some African regions such as Tanzania, Namibia, and Rwanda [74].

In terms of ancillary services, regulation is still at an early stage in the opera- tion of isolated microgrids, i.e., specialized controls are being studied and developed to be implemented and provide ancillary services to the microgrid. Many of the control devices are contained in inverters and controllers that can be unstable because of the several tasks they perform, such as current control, voltage amplification, control of the DC side of the ESS generator, and Maximum Power Point Tracking (MPPT).

In microgrid mode, there are two main features: First, any variation or unbalance in the active and reactive power affects the voltage and the frequency of the system. Second, these variations must be assumed by all DERs in the microgrid because there is no slack bus [75].

Then, the DG and ESS in an isolated microgrid behave as voltage sources that maintain the voltage and frequency required to supply electricity to the demand. That is, the active and reactive generation from DERs is based on the system characteristics, and a fast response of the resources to any voltage or frequency variation is assumed. Each resource performs a local reactive power and frequency control to change the operation point and ensure the balance of both active and reactive power [8]. Consequently, the definition and classification of microgrids are challenging, especially because the criteria for

Table 5. International experiences of isolated microgrid operation. Source: Adapted from [30], [73].

\begin{tabular}{|c|c|c|c|c|c|c|c|c|}
\hline \multirow{2}{*}{ Microgrid's name, location } & \multicolumn{4}{|c|}{ DG } & \multicolumn{2}{c|}{ ESS } & \multicolumn{2}{c|}{ Microgrid control } \\
\cline { 2 - 9 } & $\begin{array}{c}\text { Solar } \\
\mathrm{PV}\end{array}$ & Diesel & Hydro & Wind & Batteries & Others & Central & Autonomous \\
\hline $\begin{array}{c}\text { UW microgrid, United } \\
\text { States }\end{array}$ & $\mathrm{x}$ & $\mathrm{x}$ & & & & & & $\mathrm{x}$ \\
\hline Kythnos, Greece & $\mathrm{x}$ & $\mathrm{x}$ & & & $\mathrm{x}$ & & $\mathrm{x}$ & $\mathrm{x}$ \\
\hline Brinsbergen, Netherlands & $\mathrm{x}$ & & & & $\mathrm{x}$ & & $\mathrm{x}$ & \\
\hline Nanji, China & $\mathrm{x}$ & $\mathrm{x}$ & $\mathrm{x}$ & $\mathrm{x}$ & $\mathrm{x}$ & & $\mathrm{x}$ & \\
\hline Dongfushan, China & $\mathrm{x}$ & $\mathrm{x}$ & & $\mathrm{x}$ & $\mathrm{x}$ & & $\mathrm{x}$ & \\
\hline Huatacondo, Chile & $\mathrm{x}$ & $\mathrm{x}$ & & $\mathrm{x}$ & $\mathrm{x}$ & $\mathrm{x}$ & $\mathrm{x}$ \\
\hline
\end{tabular}


their development are not well defined since the characteristics and needs of each region are different [76]. Additionally, the remuneration of ancillary services in the EPS through market mechanisms has been discussed due to the obligation it entails, which discourages investments [77].

\section{THE VALUE OF DER INTEGRATION: DISCUSSION AND PROPOSALS}

Electrification of rural or isolated areas is one of the predominant problems in worldwide electrification [78]. Most countries have focused on increasing the coverage of the electricity supply without paying particular attention to whether the implemented solution is sustainable in the medium and long-term [79]. In this regard, technical sustainability refers to the ability of the system to meet current and future needs of the demand with a reliable and efficient supply by using clean and renewable energy sources [79].

Moreover, the roadmap for the implementation of smart grids in Colombia [70] holds that the deployment of smart grid technologies such as DERs, the advanced measurement infrastructure, and the modernization of electricity networks would help Colombia achieve its strategic objectives concerning energy, universal access to electricity, improving environmental sustainability, and the security and quality of the electricity supply.

Thus, and considering the diagnosis of the operation of the NIZ in Colombia and the international experiences previously mentioned, our proposal is to consider those zones as natural laboratories where it would be feasible to analyze the effects of the DER integration and the requirements for the operation by local production units. In the future, ancillary services such as voltage and frequency control can be provided in isolated microgrids along with the usual electricity supply.

It is therefore important to consider that in Colombia, as well as in many re- gions of the world, the electrification of these isolated areas is predominantly carried out by diesel generation units and some small hydro-power plants. Nevertheless, high dependence on small-scale diesel generation units imposes significant costs on the purchase of the fuel, especially for oil-importing countries. This leads to an increase in the overall costs of the system's generation and operation. It also reduces the viability of businesses related to the electricity supply chain in these areas, which (the businesses) become necessary due to the increase in government subsidies [79].

In addition, the development of isolated microgrids with a reliable, sustainable, and safe electricity supply (along with the provision of ancillary services that support DER integration) involves a number of technical details and challenges that differentiate the operation by isolated microgrids from the conventional operation of distribution networks [80]. Among these challenges, the balance between the power generated in the DG plants and the power consumed by demand stands out, because it must be further adjusted when isolated microgrids operate compared to conventional distribution networks [81], [82]. This balance within operational ranges is linked to the provision of ancillary services for voltage and frequency control, i.e., the ability of DERs to provide a reserve that increases or decreases the active and reactive power of the system while maintaining the frequency and the voltage profiles within the operational limits defined in the regulation [83].

The roadmap for the integration of smart grids in Colombia [70] focuses its scope on the integration of smart grid technologies to the NIS. It argues that thus it will have a greater potential impact by being able to participate in large-scale projects. This roadmap also enables to adapt solutions of distributed generation and storage to the NIZ, once these solutions have been successfully applied in the 
NIS. However, under this approach, the implementation of this type of projects in the most vulnerable communities would be delayed. Therefore, while DER solutions are being implemented in the NIS, pilot projects should be carried out in the NIZ, which would allow these communities to have a continuous supply of electricity in an environmentally and technically sustainable way. In addition, such projects would be a valuable source of information on the technical operation of these technologies and their economic behavior, which would contribute to fulfill Colombia's strategic objectives in terms of energy. But, in fact, there currently are more NIZ projects that include microgrids and renewable energy than projects in the NIS.

Accordingly, when the following proposal is implemented in Colombia, it will be possible to increase the impact of the benefits of DER integration and overcome some challenges of the microgrid mode of operation. This proposal seeks to define policies that regulate the provision of ancillary services with DERs (frequency control and voltage regulation in an isolated microgrid) with potential benefits, like technical sustainability in the medium and long-term operation.

The technical sustainability dimension is related to the reliability and quality of the electricity supply in the medium and long-term. In the medium term, the sustainable operation by microgrids with high DER integration could promote investments for expanding distribution networks [24], [31], [25]. In addition, due to the installation of dispersed DERs in the system, a reduction of electric losses could be envisioned [17], [28], [37] while the energy potentials of each region are exploited by connecting DGs from renewable sources near consumption centers. In the long term, the development of sustainable projects would enable the reduction of energy not supplied due to accidental disconnections through the implementation of fre- quency and voltage control as ancillary services.

Furthermore, the inclusion of ancillary services would allow the long-term operation of isolated microgrids, which constitutes a contribution to the EPS when these subsystems work interconnected. However, in order to achieve technical sustainability in the microgrid's operation, the active distribution network infrastructure must include advanced measurement and control technologies that allow different DERs to be monitored and communicated with the system operator [27], [28], [30], [78].

From the technical point of view, a technological infrastructure must be in place, including a control and communication system, automatized protections and elements of active distribution networks associated with the DER installed in the system. They enable to maintain the balance between generation and load in the isolated microgrid. This is done in order to guarantee the provision of a sustainable electricity supply in the medium and longterm despite events and disturbances that may occur within the microgrid [30], [84].

Economically, agents are expected to participate in the provision of ancillary services of frequency and voltage control in isolated microgrids driven by incentives, subsidies, differential rates, and penalties, depending on the DER involved in the system. This would guarantee the permanent upgrade and modernization of the infrastructure required for the provision of ancillary services for voltage and frequency control.

Accordingly, Table 6 shows a proposal for the definition of roles of each DER involved in the isolated microgrid in order to differentiate the responsibilities and challenges of each interconnected resource.

This work proposes a provision of primary control (voltage and frequency) carried out by conventional synchronous DG units (with primary sources such as diesel and water) due to their capacity to respond to changes and fluctuations of the demand. 
Integration of distributed energy resources in isolated microgrids: the Colombian paradigm

Table 6. Proposal for the provision of ancillary services in an isolated microgrid. Source: Authors.

\begin{tabular}{|c|c|c|c|}
\cline { 3 - 4 } \multicolumn{2}{c|}{} & \multicolumn{2}{c|}{ Challenge } \\
\hline Ancillary Services & DER & Technical & Economical \\
\hline $\begin{array}{c}\text { Primary Control (Voltage } \\
\text { and Frequency) }\end{array}$ & $\begin{array}{c}\text { Distributed Generation - convention- } \\
\text { al synchronous generator }\end{array}$ & $\begin{array}{c}\text { Maintenance } \\
\text { Primary Source }\end{array}$ & $\begin{array}{c}\text { Incentives } \\
\text { Subsidies } \\
\text { Penalties }\end{array}$ \\
\hline $\begin{array}{c}\text { Secondary control (Voltage } \\
\text { and Frequency) }\end{array}$ & Energy Storage System & $\begin{array}{c}\text { Reactive and voltage } \\
\text { control } \\
\text { Reserve } \\
\text { Metering }\end{array}$ & $\begin{array}{c}\text { Power and frequency } \\
\text { control }\end{array}$ \\
\cline { 2 - 4 }
\end{tabular}

Thus, technical challenges arise regarding the maintenance of these controls and the continuous supply of the primary source .

In the event of large unbalances between generation and demand that require the operation of secondary voltage and frequency control, the contributions should be made from the ESS (reserve) or the variation of demand consumption in order to balance generation and load again.

The experience acquired from the implementation of microgrids in the Colombian NIZ can be replicated in the NIS for several purposes: making the distribution network more flexible, allowing the distribution system to provide ancillary services to the transmission system, and making the most of the benefits of the integration of new technologies in the operation of the system.

In that sense, the pilot projects carried out in the NIZ can be considered sources of information for the development of smart grid technologies in Colombia. As a result, these initiatives could be evaluated with the assessment methodology proposed in the roadmap for the implementation of smart grids [70]. This makes the methodology not only a tool for evaluating and verifying the focus of the projects but also an instrument for the construction of databases, which would constitute a source of information for the implementation of microgrids and smart grids on a larger scale in the NIS.

\section{CONCLUDING REMARKS}

Currently, the isolated microgrid mode of operation does not consider the provision of ancillary services; therefore, the necessary infrastructure that enables an efficient and sustainable DER integration should be characterized and defined in order to optimize the benefits listed in this proposal.

Based on international experiences, the natural laboratories for the development of isolated microgrids in Colombia are the NIZ, because they have special conditions in the operation by isolated microgrids. Besides, an assignment of responsibilities and tasks to each DER is proposed for the sustainable operation of the system in the medium and long-term. However, regulatory policies should be defined to encourage the provision of ancillary services.

The implementation of microgrids in Colombian NIZ is an (almost risk-free) opportunity to study the real behavior of integrated DERs, structure a proposal for the operation of microgrids interconnected with the central system (which can provide ancillary services to the transmission system), and maximize the benefits of DER integration in distribution systems.

Colombia has promoted initiatives for the successful implementation of DERs in the NIS, which range from establishing connection requirements for distributed generation to studies for the proposal of 
incentives related to the implementation of pilot projects for the integration of smart grids technologies.

However, taking into account that the rules of operation of the distribution systems of the NIZ differ from those of the NIS, studies are necessary to identify the most appropriate mechanisms to encourage the integration of DER technologies in those areas.

This paper presents a reflection of the state of DERs in Colombia and the challenges posed by the integration of these resources in the distribution system. It also proposes to use the NIZ as natural laboratories where it would be possible to analyze the economic and technical effects of DER integration and the requirements for operation by isolated microgrids. This approach would provide valuable information for future DER implementations, both in the NIZ and the NIS. Furthermore, it would allow vulnerable communities to have sustainable access to electricity.

\section{ACKNOWLEDGMENTS}

The research for this paper was supported by Universidad Nacional de Colombia through Manizales Research Department (DIMA) as part of the project "Design of operational strategies for the efficient integration of distributed energy resources in distribution networks in Colombia", under code 35911, developed by the research group in Environmental Energy and Education Policy (E3P).

Besides, we thank Olga Umaña C. (www.palabrasclave.com.co) for the revision of this paper.

\section{REFERENCES}

[1] Q. Wang, C. Zhang, Y. Ding, G. Xydis, J. Wang, and J. Østergaard, "Review of realtime electricity markets for integrating Distributed Energy Resources and Demand Response," Appl. Energy, vol. 138, pp. 695-
706, 2015.

[2] C. Eid, P. Codani, Y. Perez, J. Reneses, and R. Hakvoort, "Managing electric flexibility from Distributed Energy Resources: A review of incentives for market design," Renew. Sustain. Energy Rev., vol. 64, pp. 237-247, 2016.

[3] D. Neves, M. C. Brito, and C. A. Silva, "Impact of solar and wind forecast uncertainties on demand response of isolated microgrids," Renew. Energy, vol. 87, pp. 1003-1015, Mar. 2016.

[4] F. Martin-Martínez, A. Sánchez-Miralles, and M. Rivier, "A literature review of Microgrids: A functional layer based classification," Renew. Sustain. Energy Rev., vol. 62, pp. 1133-1153, 2016.

[5] S. M. Nosratabadi, R. Hooshmand, and E. Gholipour, "A comprehensive review on microgrid and virtual power plant concepts employed for distributed energy resources scheduling in power systems," Renew. Sustain. Energy Rev., vol. 67, pp. 341-363, Jan. 2017.

[6] F. Adinolfi, G. M. Burt, P. Crolla, F. D. Agostino, M. Saviozzi, and F. Silvestro, "Distributed Energy Resources Management in a Low-Voltage Test Facility," IEEE Trans. Ind. Electron., vol. 62, no. 4, pp. 2593-2603, 2015.

[7] P. Faria, Z. Vale, and J. Baptista, "Constrained consumption shifting management in the distributed energy resources scheduling considering demand response," Energy Convers. Manag., vol. 93, pp. 309-320, Mar. 2015.

[8] M. Bayat, K. Sheshyekani, M. Hamzeh, and A. Rezazadeh, "Coordination of Distributed Energy Resources and Demand Response for Voltage and Frequency Support of MV Microgrids," IEEE Trans. Power Syst., vol. 31, no. 2, pp. 1506-1516, Mar. 2016.

[9] L. Montuori, M. Alcázar-Ortega, C. ÁlvarezBel, and A. Domijan, "Integration of renewable energy in microgrids coordinated with demand response resources: Economic evaluation of a biomass gasification plant by Homer Simulator," Appl. Energy, vol. 132, pp. 15-22, Nov. 2014.

[10] T. L. Vandoorn, B. Zwaenepoel, J. D. M. De Kooning, B. Meersman, and L. Vandevelde, "Smart microgrids and virtual power plants in a hierarchical control structure," in 2011 2nd IEEE PES International Conference and Exhibition on Innovative Smart Grid Technologies, 2011, pp. 1-7.

[11] S. B. Van Broekhoven, N. Judson, S. V. T. Nguyen, and W. D. Ross, "Microgrid Study: Energy Security for DoD Installations," 2012. 
[12] R. Rashed Mohassel, A. Fung, F. Mohammadi, and K. Raahemifar, "A survey on Advanced Metering Infrastructure," Int. J. Electr. Power Energy Syst., vol. 63, pp. 473-484, 2014.

[13] J. Kwac and R. Rajagopal, "Demand response targeting using big data analytics," in 2013 IEEE International Conference on Big Data, 2013, pp. 683-690.

[14] R.-S. Liu, "An Algorithmic Game Approach for Demand Side Management in Smart Grid with Distributed Renewable Power Generation and Storage," Energies, vol. 9, no. 8, p. 654, Aug. 2016.

[15] J. A. Peças Lopes, N. Hatziargyriou, J. Mutale, and N. Jenkins, "Integrating distributed generation into electric power systems: A review of drivers, challenges and opportunities," Electr. Power Syst. Res., vol. 77, no. 9, pp. 1189-1203, 2007.

[16] S.Abu-Sharkh et al., "Can microgrids make a major contribution to UK energy supply?," Renew. Sustain. Energy Rev., vol. 10, no. 2, pp. 78-127, Apr. 2006.

[17] M. Afkousi-Paqaleh, A. Abbaspour-Tehrani Fard, and M. Rashidinejad, "Distributed generation placement for congestion management considering economic and financial issues," Electr. Eng., vol. 92, no. 6, pp. 193-201, Nov. 2010.

[18] J. Schiavo, "Distributed Energy Can Lead to Smarter Grid Planning," Clean Energy Finance Forum, 2016. [Online]. Available: http://www.cleanenergyfinanceforum.com/20 16/07/31/distributed-energy-can-lead-tosmarter-grid-planning.

[19] T. Wildi, Electrical Machines, Drives and Power Systems, 6th ed. Columbus, Ohio: Prentice Hall, 2006.

[20] M. Behrangrad, "A review of demand side management business models in the electricity market," Renew. Sustain. Energy Rev., vol. 47, pp. 270-283, Jul. 2015.

[21] F. Kreith and D. W. Pepper, Energy fficiency and Renewable Energy Handbook, 2nd ed. CRC Press, 2015.

[22] P. Palensky and D. Dietrich, "Demand side management: Demand response, intelligent energy systems, and smart loads," IEEE Trans. Ind. Informatics, vol. 7, no. 3, pp. 381-388, 2011.

[23] Observatorio Industrial del Sector de la Electrónica Tecnologías de la Información y Telecomunicaciones, "Smart Grids y la Evolución de la Red Eléctrica," 2011.

[24] Federal Energy Regulatory Commission FERC, "Benefits of Demand Response in Electricity Markets and Recommendations for Achieving Them," 2006.
[25] A. Brooks, E. Lu, D. Reicher, C. Spirakis, and B. Weihl, "Demand Dispatch," IEEE Power Energy Mag., vol. 8, no. 3, pp. 20-29, May 2010.

[26] P. Cappers, A. Mills, C. Goldman, R. Wiser, and J. H. Eto, "Mass market demand response and variable generation integration issues: A scoping study," 2011.

[27] S. P. Chowdhury, P. Crossley, and S. Chowdhury, Microgrids and Active Distribution Networks. Institution of Engineering and Technology, 2009.

[28] F. P. Sioshansi, Integrating Renewable, Distributed \& Efficient Energy. Academic Press, 2011.

[29] C. F. Calvillo, A. Sánchez-Miralles, J. Villar, and F. Martín, "Optimal planning and operation of aggregated distributed energy resources with market participation," Appl. Energy, vol. 182, pp. 340-357, Nov. 2016.

[30] N. W. A. Lidula and A. D. Rajapakse, "Microgrids research: A review of experimental microgrids and test systems," Renew. Sustain. Energy Rev., vol. 15, no. 1, pp. 186-202, 2011.

[31] M. R. Narimani, P. J. Nauert, J.-Y. Joo, and M. L. Crow, "Reliability assesment of power system at the presence of demand side management," in 2016 IEEE Power and Energy Conference at Illinois (PECI), 2016, pp. $1-5$.

[32] I.-S. Ilie, I. Hernando-Gil, A. J. Collin, J. L. Acosta, and S. Z. Djokic, "Reliability performance assessment in smart grids with demand-side management," in 2011 2nd IEEE PES International Conference and Exhibition on Innovative Smart Grid Technologies, 2011, pp. 1-7.

[33] F. Shariatzadeh, P. Mandal, and A. K. Srivastava, "Demand response for sustainable energy systems: A review, application and implementation strategy," Renew. Sustain. Energy Rev., vol. 45, pp. 343-350, May 2015.

[34] G. Ferruzzi, G. Graditi, F. Rossi, and A. Russo, "Optimal Operation of a Residential Microgrid: The Role of Demand Side Management," Intell. Ind. Syst., vol. 1, no. 1, pp. 61-82, 2015.

[35] V. Van Thong, J. Driesen, and R. Belmans, "Power quality and voltage stability of distribution system with distributed energy resources," Int. J. Distrib. Energy Resour., vol. 1, no. 3, pp. 227-240, 2005.

[36] D. Singh, R. K. Misra, and D. Singh, "Effect of Load Models in Distributed Generation Planning," IEEE Trans. Power Syst., vol. 22, no. 4, pp. 2204-2212, Nov. 2007.

[37] H. Iyer, S. Ray, and R. Ramakumar, "Voltage profile improvement with distributed 
generation," in IEEE Power Engineering Society General Meeting, 2005, pp. 16031610.

[38] A. Arango-Manrique, S. X. CarvajalQuintero, and S. Arango-Aramburo, "Contribution of Distributed Generation to Voltage Control," Ing. e Investig., vol. 31, no. 2, pp. 153-158, 2011.

[39] M. H. J. Bollen and M. Häger, "Power Quality: Interactions Between Distributed Energy Resources, the Grid, and Other Customers," Electr. Power Qual. Util. Mag., pp. 51-61, 2005.

[40] S. M. H. Nabavi, S. Hajforoosh, and M. A. S. Masoum, "Placement and sizing of distributed generation units for congestion management and improvement of voltage profile using particle swarm optimization," in 2011 IEEE PES Innovative Smart Grid Technologies, 2011, pp. 1-6.

[41] J. M. Carrasco et al., "Power-Electronic Systems for the Grid Integration of Renewable Energy Sources: A Survey," IEEE Trans. Ind. Electron., vol. 53, no. 4, pp. 1002-1016, Jun. 2006.

[42] F. P. Sioshansi, Future of Utilities Utilities of the Future, 1st ed. Boston: Academic Press, 2016.

[43] J. Vasquez, J. Guerrero, J. Miret, M. Castilla, and L. Garcia de Vicuna, "Hierarchical Control of Intelligent Microgrids," IEEE Ind. Electron. Mag., vol. 4, no. 4, pp. 23-29, 2010.

[44] Congreso de Colombia, Ley 855. Colombia, 2003.

[45] J. F. Bustos, A. L. Sepúlveda, and L. K. Triviio, "Zonas no interconectadas eléctricamente en Colombia: problemas y perspectiva," SSRN Electron. J., p. 27, 2014.

[46] Instituto de Planificación y Promoción de Soluciones Energéticas para las Zonas No Interconectadas - IPSE, "Soluciones Energéticas para las Zonas No Interconectadas de Colombia," 2014.

[47] Instituto de Planificación y Promoción de Soluciones Energéticas para las Zonas No Interconectadas - IPSE, "Informe telemetría mensual Julio 2016," 2017. [Online]. Available: https://www.datos.gov.co/Minas-yEnerg-a/Localidades-ZNI-Sin-Telemetr-aJunio-2017/32n6-8kku.

[48] Instituto de Planificación y Promoción de Soluciones Energéticas para las Zonas No Interconectadas - IPSE, "Informe mensual de telemetría - Enero 2018," 2018. [Online]. Available:

http://190.216.196.84/cnm/info_mes.php.

[49] Sistema de Gestión de Información y Conocimiento en Fuentes No Convencionales de Energía Renovable en Colombia (SGI\&C -
FNCER), "Sistemas Fotovoltaicos aislados en el municipio de Paratebueno Cundinamarca," 2018. [Online]. Available: http://www.upme.gov.co:81/sgic/?q=content/si stemas-fotovoltaicos-aislados-en-elmunicipio-de-paratebueno-cundinamarca.

[50] Unidad de Planeación Minero Energética UPME, "Informe de Proyectos de Generación de Energía Eléctrica," 2017.

[51] Instituto de Planificación y Promoción de Soluciones Energéticas para las Zonas No Interconectadas - IPSE, "El IPSE no recibirá las obras del proyecto de generación de energía eólica 'Nazareth' en la Alta Guajira.," 2012. [Online]. Available: http://www.ipse.gov.co/ipse/comunicacionesipse/noticias-ipse/459-el-ipse-no-recibira-lasobras-del-proyecto-de-generacion-de-energiaeolica-nazareth-en-la-alta-guajira.

[52] Ministerio de Minas y Energía, Decreto 1591. Colombia, 2004.

[53] Comisión de Regulación de Energía y Gas CREG, Resolución 091. Colombia, 2007.

[54] Unidad de planeación Minero Energetíca UPME, "Plan Indicativo de Expansión de Cobertura de Energía Eléctrica, PIEC 2016$2020, " 2016$.

[55] Expertos en Mercados - XM, "Informe Seguimiento Cogeneradores - Julio 2016," 2016.

[56] A. L. Michelsen, Resolución 128. Colombia, 1996.

[57] J. H. Flórez Acosta, D. Tobón orozco, and G. A. Castillo Quintero, “¿Ha Sido Efectiva La Promocion De Soluciones Energeticas En Las Zonas No Interconectadas (ZNI) En Colombia?: Un Análisis De La Estructura Institucional," Cuad. Adm., vol. 22, no. 38, pp. 219-245, 2009.

[58] Unidad de Planeación Minero Energética UPME, Ministerio de Minas y Energía, and Subdirección de Demanda, "Proyección regional de demanda de energía eléctrica y potencia máxima en Colombia,” 2016.

[59] Expertos en Mercados - XM, "Operación del SIN y Administración del Mercado,” 2016.

[60] S. X. Carvajal, J. Serrano, and S. Arango, "Colombian ancillary services and international connections: Current weaknesses and policy challenges," Energy Policy, vol. 52, pp. 770-778, Jan. 2013.

[61] Comisión de Regulación de Energía y Gas CREG, Resolución 071. Colombia, 2006.

[62] Congreso de Colombia, Ley 1715. Colombia, 2014.

[63] Comisión de Regulación de Energía y Gas CREG, Resolución 030. 2018.

[64] Comisión de Regulación de Energía y Gas CREG, Resolución 011. Colombia, 2015.

[65] Comisión de Regulación de Energía y Gas - 
CREG, Resolución 042. Colombia, 2016.

[66] Comisión de Regulación de Energía y Gas CREG, Resolución 025. Colombia, 1995.

[67] Ministerio de Minas y Energía, Decreto 2492. Colombia, 2014.

[68] Congreso de Colombia, Ley 697. Colombia, 2001.

[69] Instituto de Planificación y Promoción de Soluciones Energéticas para las Zonas No Interconectadas - IPSE, "Centinelas de la Energía," 2013. [Online]. Available: http://www.ipse.gov.co/ipse/proyectosipse/uso-racional-de-la-energia.

[70] Unidad de Planeación Minero Energética UPME, "Estudio: Smart Grids Colombia Visión 2030 - Mapa de ruta para la implementación de redes inteligentes en Colombia," 2016. [Online]. Available: http://www1.upme.gov.co/Paginas/SmartGrids-Colombia-Visión-2030.aspx.

[71] N. Hatziargyriou, Microgrids: Architectures and Control. Chichester, United Kingdom: John Wiley and Sons Ltd, 2013.

[72] "Microgrids at Berkeley Lab," 2018. [Online]. Available: https://buildingmicrogrid.lbl.gov/huatacondo. [Accessed: 30Jan-2018].

[73] O. Núñez Mata, D. Ortiz Villalba, and R. Palma-Behnke, "Microrredes en la red eléctrica del futuro - Caso Huatacondo.," Cienc. y Tecnol., vol. 29, no. 2, pp. 1-16, 2013.

[74] Intergovernmental Panel on Climate Change, Climate Change 2013 - The Physical Science Basis. Cambridge: Cambridge University Press, 2014.

[75] L. S. Xavier, J. H. de Oliveira, A. F. Cupertino, V. F. Mendes, and H. A. Pereira, "Saturation scheme for single-phase photovoltaic inverters in multifunctional operation," in 2015 IEEE 24th International Symposium on Industrial Electronics (ISIE),
2015, vol. 2015-Septe, no. September, pp. 1392-1397.

[76] M. Wiemann, S. Rolland, and G. Glania, Hybrid Mini-Grids for Rural Electrification: Lessons Learned. Alliance for Rural Electrification, 2011.

[77] S. X. Carvajal Quintero, "Análisis de Servicios Complementarios en Sistemas de Potencia Eléctricos en Ambientes de Mercados," Universidad Nacional de Colombia, 2013.

[78] International Energy Agency - IEA, "Energy for All: Financing access for the poor," in World Energy Outlook 2011, 2011, p. 52.

[79] S. C. Bhattacharyya, "Energy access programmes and sustainable development: A critical review and analysis," Energy Sustain. Dev., vol. 16, no. 3, pp. 260-271, Sep. 2012.

[80] IEEE Standards Association, IEEE 1547.4 Guide for Design , Operation, and Integration of Distributed Resource Island Systems with Electric Power Systems. Institute of Electrical and Electronics Engineers, Incorporated., 2011.

[81] A. Mehrizi-Sani and R. Iravani, "PotentialFunction Based Control of a Microgrid in Islanded and Grid-Connected Modes," IEEE Trans. Power Syst., vol. 25, no. 4, pp. 18831891, Nov. 2010.

[82] K. P. Detroja, "Optimal autonomous microgrid operation: A holistic view," Appl. Energy, vol. 173, pp. 320-330, Jul. 2016.

[83] A. Gomez-Exposito, A. J. Conejo, and C. Canizares, Electric Energy Systems Analysis and Operation. CRC Press, 2008.

[84] J. Riesz and I. Macgill, "Frequency Control Ancillary Services. Is Australia a Model Market for Renewable Integration?," CiteSeer, p. 6, 2013. 